\title{
WHAT IS THE PUBLIC PERCEPTION OF WHAT IT MEANS TO BE A GOOD CITIZEN? EMPIRICAL EVIDENCE FROM SLOVAKIA ${ }^{1}$
}

\author{
OL'GA GYÁRFÁŠOVÁ
}

\begin{abstract}
The study analyses the public perception of citizenship in Slovakia using empirical findings from the ISSP sociological survey. The paper conceptualizes the important features of citizenship, identifying three factors constituting the public's perception of citizenship. It is a perception that is relatively stable in time and informed more by the legal dimension of citizenship than the participatory one. In this respect the empirical findings do not support the theoretical assumptions usually associated with citizenship research that highlight active, participatory citizenship. The study also analyses how citizenship relates to national pride. The author finds that the normative understanding of "a good citizen" is only very loosely related to the perception of national pride.
\end{abstract}

Key words: public perception; citizenship; civic participation; national pride.

\section{Introduction}

A powerful metaphor of November 1989 was the "disenchanted citizen". The citizen "awakening" took the shape of mass protests with squares full of demonstrators and, a few months later, the historically highest voter turnout at the first free and fair parliamentary elections as well as the (re)acknowledgement of citizen rights and freedoms to the extent associated with standard democracies. The immediate years that followed presented citizenship and citizens with a number of challenges-formally, Czechoslovak citizenship came to an end and a new citizenship was born, that of the independent Slovak Republic, which would "multiply" a couple of years later through acquisition of EU citizenship. In subsequent years, sidestepping was in evidence-as the possibility of holding dual citizenship terminated. This is only a limited selection of the complex phenomenon,

\footnotetext{
1 The study is a partial output of projects APVV 0309-11 and APVV-14-0527 "Slovensko v medzinárodných porovnaniach: pred krízou a po kríze" [Slovakia in international comparisons: before and after the crisis] and "Medzi východom a západom, hodnotová integrácia alebo divergencia? Slovenská spoločnost̂ v medzinárodných komparatívnych výskumoch“ [Between East and West, integration or divergence in values? Slovak society in international comparative surveys].
}

DE GRUYTER 
indicating the intersection of legal, philosophical, political, social and cultural perspectives. The very nature of citizenship points to the benefits of adopting a multidisciplinary approach to its study and the postdisciplinarity of its importance. Not only do we have "disenchanted citizens", but we research on citizenship also reflects an acceleration of the process of "disenchantment". The sociological literature has focused on citizen participation and civil society. The "active citizen" has rightly been seen as an actor in the democratic public space, as a result of a change in the country's political culture from the culture of subject to a culture of participation - as indicated in the classic categories by G. Almond and S. Verba. However, these analyses have rarely explored—if at all—how citizens actually perceive citizenship, what they think characterizes "a good citizen", what is important for good citizenship, whether citizens take greater pride in being citizens as members of a political community, or citizens as members of a nation.

The aspiration of this study is to fill the existing gap and to analyse the normative ideas the public have about what "a good citizen" is. The additional objectives of this paper are to identify the internal dimensions that constitute this concept and what influences the way it is perceived. Next, the study examines the link between national pride and pride in being a citizen of the Slovak Republic, and the dimensions of how citizenship is understood. We can also use the research data to establish whether at the public level there are any differences between pride in nationality (of being Slovak) and pride in citizenship (of being a Slovak citizen).

Based on empirical data, the study seeks to answer the following questions: How does the public understand citizenship and what makes for a good citizen? What internal dimensions constitute the image of "a good citizen" in the eyes of the public, and which dimensions are regarded as more and as less important? To what extent are particular dimensions of citizenship connected with civic/national pride? The analysis is primarily based on findings from the ISSP survey, the Citizenship and National identity modules conducted in autumn 2014 as part of a project on "Slovakia in international comparisons: before and after the crisis". An earlier ISSP survey, Citizenship 2004, carried out in Slovakia in $2005^{2}$ is essential for comparing the indicators over time. Nevertheless, we also rely on a number of other representative surveys on this topic, mainly conducted by the Institute for Public Affairs (IVO), which enables us to track changes in public attitudes over a longer period of time as well.

The structure of the paper is as follows: the first part outlines the theoretical considerations on citizenship; the second part focuses on an analysis of the empirical data on public perceptions of what a good citizen is. The subsequent section looks at national pride and citizenship in the context of the public conception of the citizen. The study concludes with a discussion on the major findings.

\footnotetext{
2 The fieldwork for ISSP 2014 was conducted by Focus in autumn 2014, using multi-level stratification probability sampling. The sample consisted of 1,156 respondents and was representative for the adult population of Slovakia. The fieldwork for the ISSP/ 2004 Citizenship Module was carried out in April 2005 by TNS SK polling agency on a representative sample of 1,072 respondents. Detailed annotations to both surveys as well as the data files are available in the Slovak Archive of Social Data (SASD) at: http://sasd.sav.sk/sk/data_katalog.php.
} 


\section{Theoretical considerations on citizenship}

Citizenship is a key concept in political philosophy, and its history can be traced back to ancient Greece. Our aim, though, is not to trace the history of this philosophical term, which is discussed systematically in a number of publications (e.g. Višňovský, 2010; Norris, 1999; Kymlicka \& Norman, 1995; Frič, 2016). This study is more concerned with current conceptualizations which could be applicable to an empirical sociological survey. Philosopher Emil Višňovský believes that one method of overcoming the controversies between liberalism and communitarianism can be found in the way citizenship is understood today in its current revival, because citizenship is closely linked, on one hand, to the liberal idea of individual rights and freedoms, and to the communitarian idea of membership of a community, on the other. Therefore, citizenship has the potential to be an effective mediator between these two paradigms (Višňovský, 2010, pp. 47-48). Current trends also indicate that:

Our understanding of citizenship is shifting from the narrow level of political conceptualization to the wider level of socio-cultural conceptualization. Citizenship is a cultural phenomenon, and it is culture that defines its features. To define citizenship outside cultural contexts, traditions, norms, values, identities, communities etc. is insufficient nowadays... This culturological view of citizenship does not eliminate the "politological" view from the position of politics and power, because politics and power are understood as cultural phenomena (Višňovský, 2010, p. 53).

This is close to the sociological approach, and expresses the multidimensionality and complexity of citizenship.

Next section will be based on the work of those who have defined three dimensions of citizenship. This is the tri-partite model of citizenship, consisting of the scope (rules and norms of inclusions/exclusions), the content (rights and responsibilities) and the depth (richness and shallowness of the content) (Isin \&Turner, 2002, in Višňovský, 2010, p. 53). We can identify two concepts in relation to what citizenship is: (1) citizenship as a legal status, i.e. full membership of a specific political community, (2) citizenship as a desired activity where the scope and quality of the citizenship are a function of the individual's participation in the community. The first concept is referred to as "weak", and the second one as "strong" (Višňovský, 2010, p. 55). Norman and Kymlicka identify four aspects of this: citizenship as (1) legal status, (2) identity, (3) solidarity, (4) virtue (Norman \& Kymlicka, 2005), and further break it down into more detail into five implications or components of citizenship: (1) Citizenship is a status (the most fundamental concept), (2) Citizenship is a set of rights (a modern liberal concept), (3) Citizenship is self-government (a democratic concept), (4) Citizenship is an active practice (a participative concept), (5) Citizenship is an identity (psychological - ethical concept) (Weinstock, 2002, in Višňovský 2010, p. 55). It is clear from these aspects that there has been a significant shift from the classic definition by T. H. Marshall (1950) which emphasized that citizenship was a set of rights, including social ones. The relationship between citizenship and identity is crucial and extensively elaborated on in the academic literature.

Citizenship could also be defined as the relationship between the individual and the community, but while identity seems to have particularistic connotations, the notion of 
citizenship may be more theoretically universal in some contexts (Isin \& Wood, 1999). This is linked to the liberal perspective that citizenship is an objective and usually legal status, assigned by an external entity and allowing individuals to hold rights within the state whereas identity is a subjective assumption; it is a feeling of belonging.

In addition Emil Višňovský states that where citizenship is defined on the basis of its strong dimensions, the activities (practices) performed by citizens to achieve self-government and participation (understood as citizens' public activities, different forms of participation in public sphere) are at the forefront. It seems that this dimension is a norm without which citizenship does not exist and that passive citizenship, in which citizens only use their rights or privileges, recognize the authorities they are given, and obediently respect and submit to them, is not citizenship in the strict meaning. On the other hand, the mere requirement of activity and participation is not sufficient because if it were stipulated as a duty that would not ensure quality of participation, which is the issue (Višňovský, 2010, pp. 55-56).

Charles Tilly has explored the "thick" and "thin" concepts of citizenship. Writing about the citizenship as a special contract, he states:

Citizenship can then range from thin to thick: thin where it entails few transactions, rights and obligations; thick where it occupies a significant share of all transactions, rights and obligations sustained by state agents and people living under their jurisdiction ... Such a definition also permits us to trace the effects of citizenship on categories, roles and identities without conflating them (Tilly, 1996, p. 8).

From the above theoretical discussion, it is clear that current perceptions of citizenship are cultural in context (including the political dimension). It is possible to identify several dimensions, and ultimately trace a "strong" and a "weak" concept of citizenship, with clear emphasis being placed on participation, active citizenship and a bilateral relation between the state and its citizens in the former.

Furthermore, we explore the connection between national pride and/or pride in being a citizen of the Slovak Republic, and particular dimensions of perceptions of citizenship. The ISSP 2014 research data enables us to compare whether there are any differences at the public level between pride in nationality (being Slovak) and pride in citizenship (being a Slovak citizen). There has been an intense debate around the 'ethnic' conceptualization of the nation in Central Eastern European countries vis-à-vis the civic interpretation in Western Europe, especially in the 1990s in relation to the wave of nationalism, ethnically based politics, and ethnic appeals in post-communist countries. In the case of Slovakia, it has often been stated that, for various historical and contemporary political reasons, it lacks "constitutional patriotism", in other words, an affiliation to citizenship rather than to the (state-)constituting nation (e.g. Vašečka, 2008). The emphasis on "ethnos" instead of "demos" dominated the public discourse of the independent Slovak Republic particularly in its first years of existence, and it undoubtedly influenced the formation of the national as well as civic identities of its citizens. Exaltation of the "ethnos" was one of the constitutive elements of the nationalism and national populism which had the upper hand in Slovak political life particularly in the 1990s. The disadvantages of this, however, became apparent later, and are manifest in various forms. The accent on an ethnicity-based conception of citizenship can be found, for example, in the preamble 
of the Slovak constitution, which states: "We, the Slovak nation,..." and it is only later in the text that reference to the minorities can be found too: "....together with members of national minorities and ethnic groups living on the territory of the Slovak Republic". Other examples include the propagation of the legend about the "ancient Slovaks" or the erection of a statue of Slovak "King" Svätopluk in the courtyard of Bratislava Castle prior to the parliamentary elections in 2010. An ethno-centric approach is also obvious in Slovak governments' attitudes to migration and integration policies, which have been very restrictive in the long term.

However, as pointed out by a number of authors, this ethnicity-based conception of citizenship has to be viewed within its historical context, and there is no contradiction or exclusivity where civic citizenship is concerned. A modern concept of citizenship has developed in connection to the national state. As noted by O. Císař "The people, who became the source of legitimate political authority once its secular anchoring in God's will had been challenged, thus overlapped with the modern nation" (2005, p. 99). Quoting Habermas, he also notes that the internal connection between "the people" (as the source of the sovereignty of the modern state) and "the nation" (as the source of the collective identity of the citizens of that state) was, not conceptual but historical in character, and that the close relation between ethnos and demos was temporary and that state citizenship, by its very nature, was always independent of national identity (Císař, 2005, p. 99).

This is similar to M. Vašečka's thinking, who, referring to the dimensions of modern citizenship as defined by R. Brubaker-modern citizenship ought to be egalitarian, democratic, socially consequential, sacred, national, and unique — argues that

the first three dimensions follow the strictly civic tradition, while the other three come from the ethnic dimension. The first three dimensions are present in all conceptions of modern citizenship and can be found in all modern states. The differences that occur between countries are therefore also found in countries established later. In all Central European countries, citizenship is perceived, to a certain extent, to be sacred, national and unique, although there are differences between them (Vašečka, 2008, p. 200).

Other perspectives on this include comparative research conducted in Latvia, Poland and Lithuania. The author, F. Björklund, argues that the distinctions between the ethnic and civic nation, or between Western and Eastern nationalism, are based on strongly exaggerated stereotypes (Björklund, 2006, p. 94). Her own empirical survey leads her to the conclusion that there is no such thing as a uniform and specifically East European "ethnic" conception of nationality and that the civic-ethnic dichotomy is highly problematic (Björklund, 2006, p. 114).

In Slovakia, compound qualitative research has been conducted, showing how Slovakness is constructed in public space (Plichtová, Lášticová, \& Petrjánošová, 2009). The results partly contradict Björklund's research findings. The main finding of the three Slovak empirical studies (on the intelligentsia, young adults and media discourse) is that references about belonging to Slovakia and being Slovak are constructed mainly in ethnic and cultural terms (Plichtová et al., 2009). On the other hand the research revealed a clear polarization among the intelligentsia between narratives based on ethnic national and civic national principles. Since the study was conducted shortly after Slovak independence one might 
expect the public discourse to have moved away from this polarization to a slightly more civic conceptualization of Slovakness.

Summing up, the literature offers a broad variety of conceptualizations and empirical evidence. This study is limited to identifying whether there are any differences in the public perception of national and civic citizenship, and if so, to what extent.

\section{Public perception of "a good citizen"}

The ISSP survey contained nine questions that aimed to ascertain what "a good citizen" is in the normative ideas of the public. Table 1 shows that the most important characteristics are "always to obey laws and regulations" and "never to try to evade taxes", i.e. the aspects concerning respect for legally codified rules in the society. There is quite a large gap between these two items and the next items, which express solidarity and empathy: "to help people in Slovakia who are worse off than yourself" and "to try to understand the reasoning of people with other opinions". The next most important items (mean value below " 5 ") characterize citizen participation and interest in how the elected politicians conduct themselves whilst in office ("always to vote in the elections" and "to keep watch on the actions of government"). Voting is the most common and most visible form of political participation, and surveys indicate that other forms are less represented. In other words, when citizens do not vote, they are unlikely to participate in any other type of civic activity (Bútorová \& Gyárfášová, 2010). "Voting further legitimizes other democratic processes in the state, and involves an individual in the democratic political system" (Dalton, 1988, p. 41). In addition, participation in elections occupies a specific position among other forms of participation, because it is the only form of political participation that satisfies the equality criteria. "The opportunity to participate in elections ... is open to almost everybody, and every citizen may cast one ballot only, and his/her vote is of the same vote weight as the votes of the others" (Vráblíková, 2009, p. 878).

The item with the lowest rating is "to be active in social or political associations", empirically confirming that the associative potential is closely linked to participation (Bútorová \& Gyárfášová, 2010). This is rated lower than choosing to purchase particular products for environmental reasons, which is still relatively "exotic" in Slovakia. Where the participative elements of citizenship are concerned, the higher standard deviation indicates quite a large variation in views. This may be because participation is not always understood in the same way; for many citizens participation is not necessarily associated with organizations, but is more individualized and less organized. Participation has undergone changes similar to those affecting social capital and Putnam's famous metaphor of "bowling alone" could be applied here as well (Putnam, 1995). Nevertheless, in this context the item can be used as an indicator.

Compared to 2005, when the same scale was applied, the importance of particular items (we compare those applied in both surveys) did change slightly (the statistical significance was low or none); however, for us the most important finding is that there was no change in the ranking of the most important parameters of "a good citizen". These remain the same as ten years ago. This indicates considerable stability in the public image of "a good citizen". 
Table 1. Notion of a good citizen ("There are different opinions as to what it takes to be a good citizen. As far as you are concerned personally on a scale of 1 to 7 , where 1 is not at all important and 7 is very important, how important is it?")

\begin{tabular}{|l|c|c|}
\hline & Mean & St. deviation \\
\hline Always to obey laws and regulations & 5.83 & 1.508 \\
\hline Never to try to evade taxes & 5.61 & 1.645 \\
\hline To help people in Slovakia who are worse off than yourself & 5.10 & 1.493 \\
\hline To try to understand the reasoning of people with other opinions & 5.00 & 1.460 \\
\hline Always to vote in elections & 4.91 & 1.802 \\
\hline $\begin{array}{l}\text { To help people in the rest of the world who are worse off than } \\
\text { yourself }\end{array}$ & 4.48 & 1.658 \\
\hline To keep watch on the actions of government & 4.35 & 1.819 \\
\hline $\begin{array}{l}\text { To choose products for political, ethical or environmental } \\
\text { reasons, even if they cost a bit more }\end{array}$ & 3.91 & 1.700 \\
\hline To be active in social or political associations & 3.45 & 1.834 \\
\hline
\end{tabular}

Source: ISSP Slovakia 2014.

Table 2. Comparison of the most important attributes of "a good citizen", 2005 - 2014

\begin{tabular}{|l|c|c|}
\hline & Mean 2005 & Mean 2014 \\
\hline Always to obey laws and regulations & 6.17 & 5.83 \\
\hline Never to try to evade taxes & 6.01 & 5.61 \\
\hline To help people in Slovakia who are worse off than yourself & 5.44 & 5.10 \\
\hline To try to understand the reasoning of people with other opinions & 5.45 & 5.00 \\
\hline Always to vote in elections & 5.20 & 4.91 \\
\hline
\end{tabular}

Source: ISSP Občianstvo/Citizenship 2004 / April 2005; ISSP Slovakia 2014.

We used exploratory factor analysis to obtain the internal variability of how the concept of citizenship is understood. ${ }^{3}$ The three factors extracted explain $77 \%$ of the variability, a high rate. The first factor, which explains $27.3 \%$ of the variability, relates to these two strong, important items confirming that citizenship is understood as a legal commitment. We labelled it the legislation or "legalistic" factor. It indicates obedience, which cannot be

\footnotetext{
3 We excluded "to choose products for political, ethical or environmental reasons, even if they are a bit more expensive" from the analysis, since this behaviour is not (yet) common in Slovakia. We applied varimax rotation, and we specified three factors as the criterion of extraction.
} 
questioned as such; however, it represents a more one-way and vertical relation between the state and the citizen, rather than the citizen being an interactive subject. The second factor explains $26.3 \%$ and combines characteristics related to help and empathy, and citizenship as a commitment to help others; this is the solidarity factor. The third factor $(23.4 \%$ of the variability) combines participative elements of citizenship; this is the participation factor. Undoubtedly, one could object that had the items in the questionnaire been set out differently, other dimensions could have emerged. However, the reliability for the characteristics set this way shows a high rate of cohesion among particular items (Cronbach's Alpha $=.855$ ), which indicates the measure of how people perceive citizenship has high validity.

Table 3. Rotated factor matrix - importance of attributes of "a good citizen"

\begin{tabular}{|l|c|c|c|}
\hline \multicolumn{1}{|l|}{} & \multicolumn{2}{|c|}{ Factors } \\
\cline { 2 - 4 } & $\mathbf{1}$ & $\mathbf{2}$ & $\mathbf{3}$ \\
\hline q1 . Always to vote in elections & .592 & & .561 \\
\hline q2 . Never to try to evade taxes & .884 & & \\
\hline q3 . Always to obey laws and regulations & .870 & & \\
\hline q4 . To keep watch on the actions of government & .324 & & .797 \\
\hline q5 . To be active in social or political associations & & & .851 \\
\hline $\begin{array}{l}\text { q6 . To try to understand the reasoning of people with other } \\
\text { opinions }\end{array}$ & .352 & .573 & .306 \\
\hline q8 . To help those people in Slovakia that are worse off than you & & .889 & \\
\hline $\begin{array}{l}\text { q9 . To help people in the rest of the world who are worse off } \\
\text { than yourself }\end{array}$ & & .864 & \\
\hline
\end{tabular}

Note: Only values higher than 0.30 are included in the factor matrix.

Source: ISSP Slovakia 2014.

There is an internal logic to the empirical finding on the three factors indicating the attributes of what good citizenship is perceived to be. Returning to the theories on citizenship, it can be said that a rather "weak" concept dominates in the public's notions, as it concerns legal status, certain obligations (and rights) arising from formal citizenship and citizenship is perceived as a unilateral state-citizen relation. The second most important factor relates to the solidarity and empathy present in definitions of citizenship as a cultural phenomenon and as a relation-based element within the community, which is mainly horizontal in character. The weakest dimension in the public's notions is the one most emphasized by the majority of studies completed after November 1989-participation, active citizenship, public (civic) control of power, participation in elections, active engagement in civic or political associations and alike. The image obtained of the priorities of the public and NGO activists is, therefore, considerably skewed, and "thick" or "strong" citizenship has not become rooted in the perception of the public (so far?). 
Civic participation-which we understand to be the active participation of citizens in public life, as an indicator of active citizenship - is generally considered to be one of the main democratic values ${ }^{4}$ as well as a key factor in democratic consolidation-without active citizens or democrats, without the multi-layer and diverse participation of citizens in the governance of public affairs, it is impossible to speak about the full-fledged functioning of democracy. This is even truer for post-communist societies with their powerful heritage of non-democratic regimes, which fought against (or even sanctioned) authentic activities, and from their position of power, required citizens to engage in pseudo-participation.

In several studies (Vrábliková, 2009; Bútorová \& Gyárfášová, 2010; Plichtová, 2010; Bútora et al., 2012; Bútorová, 2016; Frič, 2016) a drop in potential participation after the initial post-November years was recorded, which raises some concern. The reasons for this are varied; for instance Atilla Ágh mentions the participation deficit and participation paradox. He argues that the consolidated democracies of CEE have not generated citizens' civic culture and participatory democracy. He highlights the 'participation paradox': "so far the initial large mobilisation at the very beginning of systemic change has not generated a citizen's culture and participatory democracy as a new tradition in the ECE states" (Ágh, 2010, p. 76).

Ondřej Císař is even more critical and points out that civic societies in post-communistic countries are restricted in being able to set their own priorities in civic activities. In relation to criticisms of global civic society, he is also critical of the external financing for civic activities in post-communist societies, claiming that "these programmes hindered loyal activists from defining their own priorities for which they could obtain financial support. On the contrary, these were trans-national players who decided local priorities" (Císař, 2005, p. 102). The latest surveys show that "the circle of active citizens-people who, in various ways, become engaged in solving the problems facing society and in governing public affairs" is shrinking (Bútorová, 2016, p. 224). It has been repeatedly confirmed that "people with a higher level of civic activism have a more favourable view of the direction the country is headed in; while alarmist attitudes tend to be connected to civic disgust, with succumbing to the feeling of helplessness and passivity" (Bútorová, 2016, p. 218), which also indicates important differences in the attitudes of active and passive citizens. Other findings reflect the following:

... a slight increase in the rate of past participation, but mainly a greater preparedness to participate in the future, is typical among people who are concerned most about corruption, clientelism and the misappropriation of public property; persistent problems in the coexistence between the Roma and non-Roma; the emergence of extremists and their increasing influence; EU difficulties in coping with the current crises. These are the people who put more emphasis on the fact that in a democratic society the rights of minorities need to be respected as well, and this is probably the reason why they are more appreciative of the beneficial effects of NGOs involved in helping immigrants integrate in society; speaking out against racial, ethnical and opinion intolerances; seeking to improve the living situation of the Roma community; dealing with the sexual minority issues and promoting their rights (Bútorová, 2016, p. 220).

\footnotetext{
4 Prominent political sociologist L. Diamond considers citizens' right to participation to be one of the four central democratic values. The other three are political freedoms, equality before the law and equality of rights for women (Diamond, 1999).
} 
Being prepared to become an active citizen is driven by a greater interest in and sensitivity to societal problems. The current surveys can be seen as a warning signal that the numbers prepared to participate are in decline, and this is despite participation levels having rarely been reached to the extent potentially indicated by the respondents. Instead it represents an ideal, of what should /could be. Compared to ten years ago, this potential has dropped. Though some anecdotal observations may point to an increase civic participationmainly in response to challenges in specific areas like environmental issues or political corruption-activities are still limited to relatively small layers of society. On the other hand we are seeing growth in new forms of civic participation being stimulated by new technologies. However, more specifically focused research is required to determine their scope and impact.

Summing up, the analysis of perceptions of what the important attributes of citizenship might be shows that the expectations "good citizens" have of their own active participation do not fully correspond to the general public's image of a good citizen. The assumption that the ethos of citizen participation will continue automatically and linearly in the years following democratic consolidation simply because it can is not supported by our empirical evidence.

\section{Pride in civic citizenship or in ethnic nation?}

As mentioned in the introduction, references to ethnicity-based citizenship are often made in connection with Slovakia. That this conception of citizenship prevails can also be gleaned from the long-term attitudes and opinions of the public. In Slovakia there is typically a considerable social distance between the majority group and ethnic minorities, foreigners and, generally, against any kind of "otherness" (Vašečka, 2009; Gallová Kriglerová \& Kadlečíková, 2012). In the first two decades after 1989, this distance was mainly visible in relation to the traditional autochthonous minorities, mainly the two most numerous-the Hungarian and Roma minorities. After 1989, intolerance and a questioning of the need to respect ethnic minority rights became an important political topic and a key dividing line in the political contest. Nationalism and national populism were an obstacle to the consolidation of liberal democracy and Slovakia's integration ambitions. The ethnical mobilization did not weaken until 2010. This was down to a coincidence of several factors including the establishment of Most-Híd a political party whose ambition was to be a civic, not ethnicallybased political power, and the failure of the SNS (the Slovak National Party) and SMK (the Party of Hungarian Coalition) to win enough votes. In addition, there was also an external factor-a non-nationalistic pro-reform government coalition in Slovakia in 2010-2011 and the Viktor Orbán government in Hungary, which meant the nationalistic game could no longer be played. The "complementarity of populisms" that was in place prior to the 2010 elections disappeared, not to be renewed after the second Robert Fico government took power in 2012. However, at that time it was already clear that the weakening of the national agenda would not mean a complete retreat from the Slovak politics, and it remained a "dormant potentiality" which was again mobilized, even though this time mainly immigrants were "the others".

The existence of an ethnically-based conception of the state is clearly illustrated in the finding that as many as $68 \%$ of the respondents agreed with the statement saying that 
"Slovakia is the country of Slovaks, and it should remain like this" (Gallová Kriglerová \& Kadlečíková, 2012, p. 10). This view expressed by the public certainly reflects the overall setting in which political elites nourish the ethno-centrist perception by taking symbolic steps or adopting real policies. The authors of the 2012 survey wrote with foresight:

The ethno-centrist perception of the society may be a hot-bed of support for rightist extremism. If extremist movements build their rhetoric around the inequality of various groups of citizens and on limiting their rights, it is reasonable to worry that, under certain circumstances; they will gain public support, especially where public sensitivity on the issue of non-discrimination and minority human rights is minimal” (Gallová Kriglerová \& Kadlečíková, 2012, p. 10).

The ISSP 2014 survey provides us with a unique opportunity to compare national ethnic pride on the one hand and civic pride on the other, as the questionnaire contained both questions.

Table 4. National vs. civic pride (in \%)

\begin{tabular}{|l|c|c|c|}
\hline & $\begin{array}{c}\text { "How proud are you } \\
\text { of being Slovak" } \\
\text { (responses by ethnic } \\
\text { Slovaks only) }\end{array}$ & $\begin{array}{c}\text { "How proud are you } \\
\text { of being a citizen of } \\
\text { Slovakia?" (responses } \\
\text { by ethnic Slovaks only) }\end{array}$ & $\begin{array}{c}\text { "How proud are you } \\
\text { of being a citizen of } \\
\text { Slovakia?" (all) }\end{array}$ \\
\hline very proud & 34.0 & 28.4 & 25.9 \\
\hline somewhat proud & 54.5 & 58.0 & 58.4 \\
\hline not very proud & 9.5 & 11.3 & 13.1 \\
\hline not proud at all & 2.0 & 2.4 & 2.6 \\
\hline
\end{tabular}

Sources: ISSP Slovakia 2014.

It is of course necessary to distinguish between the respondents of ethnicities other than Slovak (this group predominantly consists of ethnic Hungarian Slovak citizens) and to compare them with the responses of ethnic Slovak citizens. The descriptive data reveal that strong pride (very proud) in Slovak citizenship is a little weaker than pride in being Slovak (34.0 : 28.4). However, if we add up both degrees of the four-degree scale, we get very similar values $(88.5: 86.4)$, and the difference is not statistically significant.

The difference in pride is explained by V. Krivý: "mainly by extended emotional settings in relation to the nation, in contrast to the more rational and pragmatic setting in relation to citizenship and the state (unless the fight for an independent state is at its height)f" (Krivý, 2016, p. 48). In other words, civic pride is closer to the pragmatic, more paper-based relationship, and is not a source of emotional identification to the same extent.

M. Bahna employed a different approach to comparing pride in the nation and pride in citizenship. When the two questions are combined three quarters of the ethnic Slovak respondents responded to both questions identically. In this research $5.8 \%$ of responses were missing, and in total $11.9 \%$ of respondents were more proud of being Slovak in the national 
sense, with $4.6 \%$ of respondents taking greater pride in citizenship, i.e. the respondents were on average more proud of "being Slovak" than of holding Slovak citizenship, and this difference is statistically significant. Pride in nationality is higher across all groups of respondents, though it is much more obvious in the case of women (Bahna, 2015a). Between 1996 and 2014 an increase in national pride was recorded, but at the same time pride is less related to nationalistic or xenophobic attitudes (Bahna, 2015b). Our assumption is that recently national pride has become less connected to the nationalistic understanding associated with the first years of Slovak independent statehood and when the slogan "We don't want foreign things, and will not give up what is ours!" was being strongly promoted in the political discourse. Based on this trend (although we cannot compare it with civic pride), it is possible to accept that the civic dimension of pride has strengthened as has national selfconfidence.

\section{Civic pride and perception of citizenship}

Let's go back to conceptions of citizenship and the link to pride - How does the degree of pride influence the understanding of citizenship, specifically the three dimensions identified? Given the empirical distribution of responses on the four-degree scale of pride, we reduced the scale to a three-degree scale $(1=$ very proud; $2=$ somewhat proud; $3=$ not very proud + not proud at all). We looked at the differences in the way the groups understood this definition of citizenship depending on degree of pride using pairwise comparisons, t-tests for unequal variance (variables: legislation and participation) $)^{5}$, analysis of variance (ANOVA) and the Duncan test for multiple comparisons (variable solidarity). For each dimension, the average value of the two items that saturated the given factor most was used as a dependent variable.

The results indicate statistically significant differences in the perception of the importance of particular dimensions of citizenship among the groups defined based on degree of pride; however, this distinction is different for each group in relation to each dimension. In the case of the legislation dimension, there is a statistically significant different between each of the three groups defined based on degree of pride: the legislation dimension is most important for "the very proud" group, (mean is 6.12), significantly less important for "the somewhat proud" group (5.76) and statistically significantly the least important for "the not proud" group (mean $=4.91$ ). In other words, the dimension perceived to be most important by the public clearly leads to the differentiation of three clusters of pride. Solidarity is significantly the least important for "the not proud" group (mean is 4.32) compared to the two other groups (means are 4.82 and 5.04), i.e. solidarity only distinguishes a smaller group of those that are not proud. In the case of the third dimension-participation, "the very proud" group (mean $=4.25)$ is significantly different from "the somewhat proud" and "the not proud at all" group (means are 3.84 and 3.60), i.e. only those expressing considerable, strong pride place participation higher than the rest of the population.

5 The assumptions for the analysis of variance (ANOVA) were not satisfied for these two dimensions. 
What does this tell us? Most importantly, each of the identified dimensions is most important for very proud citizens. Apart from this main finding, however, there is no general connection between the normative understanding of citizenship and pride in being a citizen. To analyse this more specifically, it is important to break down the concept of citizenship further and use a qualitative approach to identify specific content and narratives. The empirical analysis, therefore, shows that pride of citizenship and perception of the importance of particular dimensions of citizenship do not follow a single pattern, but a segmented one.

\section{Final discussion}

Citizenship and active citizens are essential to a democratic political culture. Without these, it could easily become a form of illiberal, semi-authoritative government. At the end of the third decade of the democratic regime, Slovakia still faces a number of threats - a high level of corruption, elements of oligarchy, electoral popularity of right-wing extremism, erosion of trust in democratic institutions and mainstream media, and, last but not least, apathy and a lack of interest among a significant section of the public.

Our analysis explores how the public sees "a good citizen", i.e. the normative ideal. The results show that the most frequently mentioned characteristics of "a good citizen" relate to legislation and the observance of certain legal responsibilities and standards, and not, as protagonists of civic society might expect participation and public control of power. These come at the very "tail end" of the importance rating. Solidarity is the third identified dimension of the conception of citizenship.

In terms of the theory, it is thus possible to state that a weak or "thin" (formalized, transaction-based) perception of citizenship prevails over a strong "thick" (more participatory, cultural-based) one. According to the public's view, participation is the least important part of being a good citizen. This finding contradicts expectations that "disenchanted" citizens within a democratic political culture long for participationdeemed to be proof of an interest in public affairs and active participation in governance. On the other hand, the decline in participation and general interest in politics, as repeatedly documented by surveys (compare e.g. Gyárfášová, 2015), are indicative of the public's priority regarding the conception of "good citizenship".

The linking between the public image of "a good citizen" and "an active citizen"necessary requirement of a vibrant democratic society is a topic for more in-depth research. Our results support the argument that the public's perception focuses on the relationship between the individual and the community-on the state, the legal status associated with rights and duties - and not on an identity that is subjectively assumed and related to a feeling of belonging. Further research should focus more on what a civic versus an ethnic identity means, and the extent to which belonging to the state or to the ethnic group generates potential participation. More engaged citizens should not just obey the law and pay taxes (although this could be seen as the minimum requirement) but also keep watch over the government and actively participate in public life.

Citizenship is linked to citizen's pride. The data show that pride in citizenship is a widespread value; more than one quarter of the respondents stated that they were "very 
proud" and a further $58 \%$ somewhat proud, while less than $16 \%$ claim not to be very proud or not proud at all. We wanted to find out which is positioned higher-national pride or civic pride. The survey performed as part of the ISSP Citizenship module confirmed our assumptions that national pride is stronger than civic pride. However, comparison of the saturation of national pride in 1995 and in 2014 indicates that national pride is slipping out of the narrow confines of ethnic nationalism, which was a typical feature in the 1990s. If this development continues and there is no extensive recurrence of national populism, one can expect civic pride to strengthen in the future. These results indicate that the nature of Slovakness has changed since the research by Plichtová et al. (2009), moving more towards civic-national principles and away from the ethnic dominated discourse. This hypothesis can be backed up by contextual factors - the decline of anti-Hungarian nationalism within the political discourse or more pro-EU statements by the government. However, to obtain more detailed findings on how Slovakness is constructed today-25 years after independencewould require special investigation.

Our analyses did prove the linkage between pride in being a Slovak citizen and the normative image of a good citizen. Put simply — the greater the pride the more important each dimension is, but there are some complex differences. Where participation is concerned, "the very proud" group stands out significantly from "the somewhat proud" and "the not proud at all" group, which means that only those expressing considerable, strong pride place participation higher than the rest of the population. Of course we cannot prove the direction of causality; nevertheless, these results indicate a strong correlation, opening up the debate to include another factor of civic participation. The available data was limited in scope, but in addition to the findings obtained, it points to a potential future direction for research on citizenship, civic pride and participation.

\section{Acknowledgement}

The author would like to thank RNDr. Anna Hrabovská, CSc. for her consultations on statistical data processing and to two anonymous reviewers for their helpful and constructive comments that contributed to improving the final version of the paper.

\section{References}

Ágh, A. (2010). Post-accession crisis in the new member states. Progressing or backsliding in the EU? Studies of Transition States and Societies, 2(1), 74-95. http://www.tlu.ee/stss/wp-content/ uploads/2010/06/STSS-vol2-agh-1k_74-95.pdf (accessed December 6, 2016)

Bahna, M. (2015a). Hrdí Slováci, alebo hrdí občania? Správa z metodologického experimentu. Prezentácia v rámci stretnutia tímu projektu APVV 14-0527. [Proud Slovaks or proud citizens? Report from a methodological experiment. Presentation at the team meeting]. Bratislava: Sociologický ústav SAV. http://www.sociologia.sav.sk/cms/uploaded/2241_attach_bahna_ hrdost_experiment.pdf (accessed January 10, 2017)

Bahna, M. (2015b). Dve desatročia národnej identity v krajinách bývalého Československa: Prečo sú dnes Slováci viac hrdí ako Česi? Bratislava: Ústavný seminár Sociologického ústavu SAV. [Two decades of national identity in countries of former Czechoslovakia: Why Slovaks are more proud than the Czechs? Research seminar of the Institute for Sociology, SAS]. http://www.sociologia. sav.sk/cms/uploaded/2175_attach_bahna_seminar_18032015.pdf (accessed January 10, 2017) 
Björklund, F. (2006). The East European 'ethnic nation' - Myth or reality? European Journal of Political Research, 45, 93-12.

Brubaker, R. (1996). Nationalism reframed: Nationhood and the national question in the newEurope. Cambridge: Cambridge University Press.

Bútora, M., Bútorová, Z., \& Strečanský, B. (2012). Active citizenship and the nongovernmental sector in Slovakia. Trends and perspectives. Bratislava: Civic association VČELÍ DOM.

Bútorová, Z., \& Gyárfášová, O. (2010). Občianska participácia: trendy, problémy, súvislosti. [Civic participation: Trends, issues and context]. Sociológia, 42(5), 447-491.

Bútorová, Z. (2016). Občianska spoločnost’ očami verejnosti [Civil society seen through the eyes of public]. Správa zo sociologického výskumu. In Stav, trendy, potreby a možnosti rozvoja občianskej spoločnosti na Slovensku (pp. 175-226). Bratislava: Inštitút pre verejné otázky, PDCS, o. z.Centrum pre filantropiu. http://www.ivo.sk/buxus/docs//publikacie/subory/Stav_trendy_ potreby_moznosti_rozvoja_OS_na_Slovensku_2016.pdf (accessed January 19, 2017).

Císař, O. (2005). Na cestě ke společnosti sveto občanů? Nevládní organizace, sociální hnutí a „,noví“ aktivisté vňe státních hranic. [Towards a society of global citizens? Non-governmental organizations, social movements and "new" activists beyond borders]. Sociální studia, 1, 87-109.

Dalton, R. J. (1988). Citizen politics in western democracies: Public opinion and political parties in the United States, Great Britain, West Germany, and France. Chatham, New Jersey: Chatham House Publishers.

Diamond, L. (1999). Developing democracy. Baltimore: Johns Hopkins University Press.

Frič, P. (Ed.) (2016). Občanský sektor v ohrožení? [The civil sector under threat?] Praha: Slon.

Gallová Kriglerová, E., \& Kadlečíková, J. (2012). Verejná mienka v oblasti pravicového extrémizmu. Výskumná správa. [Public opinion in the sphere of far-right extremism. Survey Report.] Bratislava: Nadácia otvorenej spoločnosti - Open Society Foundation.

Gyárfášová, O. (2015). To sladké slovo demokracia ... Spokojnosê s demokraciou a politické odcudzenie na Slovensku. [This sweet word democracy ... Satisfaction with democracy and political alienation in Slovakia]. Sociológia, 47(4), 365-389.

Habermas, J. (1996). Between facts and norms. Contributions to a discourse theory of law and democracy. Cambridge, Mass.: The MIT Press.

Isin, E.F., \& Wood, P.K. (1999). Citizenship and identity. London: SAGE Publications.

Isin, E.F., \& Turner, B. S.(2002). Handbook of citizenship studies. London: SAGE Publications.

Krivý, V. (2016). Národná hrdosê a súvisiace postoje. Vybrané zistenia z výskumu ISSP Slovensko 2014. [National pride and related attitudes. Selected findings from the ISSP Slovakia 2014 survey]. Slovenský národopis 64(1), 47-59.

Kymlicka, W., \& Norman, W. (1994). Return of the citizen: A survey of recent work on citizenship theory. Ethics, 104(2), 352-376.

Marshall, T. H. (1950). Citizenship and social class and other essays. Cambridge: Cambridge University Press.

Norman, W., \& Kymlicka, W. (1995). Citizenship. In R.G Frey \& C. H. Wellman (Eds.). A companion to applied ethics (pp. 210-223). Oxford: Wiley Blackwell.

Norris, P. (Ed.). (1999). Critical citizen. Global support for democratic government. New York: Oxford University Press.

Plichtová, J., Lášticová, B., \& Petrjánošová, M. (2009). Konštruovanie slovenskosti vo verejnom priestore [Constructing Slovakness in public space]. Bratislava: Kabinet výskumu sociálnej a biologickej komunikácie SAV.

Plichtová, J. (2010). Občianska deliberatívna demokracia a podpora jej cielov na Slovensku [Goals of civic deliberative democracy and its support in Slovakia]. Sociológia, 42(5), 516-547.

Putnam, R. (1195). Bowling alone: America's declining social capital. Journal of Democracy, 6 (1), 65-78. 
Tilly, C. (1996). Citizenship, identity and social history. Cambridge: Press Syndicate of the University of Cambridge.

Vašečka, M. (2008). Nationalized citizenship in Central European countries. In M. Vašečka (Ed.), Nation űber Alles. Processes of redefinition and reconstruction of the term nation in Central Europe (pp. 199-215). Bratislava: Centre for the Research of Ethnicity and Culture.

Višňovský, E. (2010). Občianska participácia ako problém kultúry. [Civic participation as a problem of culture]. In J. Plichtová (Ed.), Občianstvo, participácia a deliberácia na Slovensku (pp. 45-82). Bratislava: Veda.

Vráblíková, K. (2009). Politická participace a její determinanty v postkomunistických zemích. [Political participation and its determinants in post-communist countries]. Sociologický časopis/ Czech Sociological Review, 45(5), 867-897.

Faculty of Social and Economic Sciences,

Comenius University,

Mlynské luhy 4,

82105 Bratislava,

Slovakia

Email: olga.gyarfasova@fses.uniba.sk. 